\title{
Anti-latency agents to purge HIV reservoirs
}

\author{
Santiago Moreno \\ From 17th International Symposium on HIV and Emerging Infectious Diseases (ISHEID) \\ Marseille, France. 23-25 May 2012
}

The persistence of latent HIV-infected cellular reservoirs represents the major hurdle to virus eradication with highly active anti-retroviral therapy (HAART), since latently infected cells remain a permanent source of viral reactivation. HIV establishes a persistent infection in CD4 $+\mathrm{T}$ lymphocytes (and to a lesser extent in macrophages as well), creating a persistent reservoir consisting mainly of latently infected resting memory CD4+ T cell. Although pre- and post-integration latencies have been described in HIV-1, the reservoir that appears to be the major barrier to eradication is composed of latently infected cells carrying an integrated provirus that is transcriptionally silent.

It has been suggested that reactivation of the latent reservoirs could allow effective targeting and possible eradication of the virus. Immunoactivation therapy to reduce the latent pool of HIV by treatment with the antiCD3 antibody OKT-3 alone or in combination with interleukin-2, substantially failed to significantly decrease the viral reservoir. Non-specific T-cell activation may induce high-level viral replication above a level that can be fully contained by ART, while increasing the susceptibility of uninfected cells.

Selective targeting of HIV provirus via agents that induce the expression of quiescent HIV, but have limited effects on the uninfected host cell is an alternate approach to attack latent HIV. Activation from latency to completion of the replication cycle should result in lytic cell death of CD4+ T cells. Multiple mechanisms that contribute to the maintenance of proviral latency could be targeted to activate the latent virus. As examples of potentially useful agents, IL-7 can reactivate HIV-1 in latently infected cells in vitro through the induction of the Janus kinase-signal transducer and activator of transcription (JAK-STAT) signalling pathway. The use of different chemical compounds targeting the PKC signalling pathway (prostratin, bryostatin) has also been proposed as a means of reactivating viral reservoirs. Finally, HDAC blocking is an attractive potential means of inducing

Ramón y Cajal Hospital, Madrid, Spain broad reactivation of HIV-1 reservoirs, and promising results have been achieved using the HDAC inhibitor vorinostat.

Published: 25 May 2012

doi:10.1186/1742-4690-9-S1-116

Cite this article as: Moreno: Anti-latency agents to purge HIV reservoirs. Retrovirology 2012 9(Suppl 1):I16.
Submit your next manuscript to BioMed Central and take full advantage of:

- Convenient online submission

- Thorough peer review

- No space constraints or color figure charges

- Immediate publication on acceptance

- Inclusion in PubMed, CAS, Scopus and Google Scholar

- Research which is freely available for redistribution
() Bïomed Central
C Biomed Central

(c) 2012 Moreno; licensee BioMed Central Ltd. This is an Open Access article distributed under the terms of the Creative Commons
Attribution License (http//creativecommons.org/licenses/by/2.0), which permits unrestricted use, distribution, and reproduction in any medium, provided the original work is properly cited. 